\title{
Legal Analysis Of Human Trafficking Case As A Transnational Organized Crime That Is Threatening State Security
}

\author{
Yuda Prasetya \\ Faculty of Law, State University of Semarang \\ Jl. Kampus Timur, Sekaran, Gunung Pati, Semarang City, Central Java 50229
}

\author{
Article Info: Submitted May 9, 2020 Accepted May, 9, 2020 \\ Published
}

\begin{abstract}
s :
Human trafficking is a form of transnational crime. One of the cases that occurred in 2019 was the torture of one of the Female Workers even being made a sexual gratification is one proof of the cruelty of human trafficking. Several Conventions have been held to prevent human trafficking. The UN in 2000 issued the Palermo Protocol on Preventing, Eradicating and Punishing Trafficking in Persons. The perpetrators of human trafficking have violated human rights because of exploitation. The Government of Indonesia issued The Act Number 21 of 2007 concerning the Eradication of the Criminal Act of Trafficking in Persons as an action to prevent trafficking in persons. Efforts to protect victims are also carried out by protecting, helping to resolve victims' problems and repatriating victims.

Keywords: Human Trafficking, Exploitation, Protection.
\end{abstract}

\section{Abstrak:}

Perdagangan manusia merupakan salah satu bentuk kejahatan transnasional. Salah satu kasus yang terjadi pada tahun 2019 yaitu disiksanya salah satu Tenaga Kerja Wanita bahkan di jadikan pemuas seksual merupakan salah satu bukti kekejaman perdagangan manusia. Beberapa Konvensi telah diadakan sebagai upaya pencegahan perdagangan manusia. PBB pada tahun 2000 mengeluarkan Protokol Palermo tentang Mencegah, Memeberantas, dan Menghukum Tindak Pidana Perdagangan Orang. Pelaku perdagangan manusia telah melanggar hak asasi manusia karena melakukan ekploitasi. Pemerintah Indonesia mengeluarkan Undangundang Nomor 21 Tahun 2007 tentang Pemberantasan Tindak Pidana Perdagangan Orang sebagai tindakan untuk mencegah perdagangan manusia. Upaya perlindungan terhadap korban juga dilakukan dengan melindungi, membantu penyelesaian masalah korban dan memulangkan korban.

Kata kunci : Perdagangan Manusia, Eksploitasi, Perlindungan.Kata

\section{Citation :}

Prasetya, Yuda. (2020). Legal Analysis Of Human Trafficking Case As A Transnational Organized Crime That Is Threatening State. Lex Scientia Law Review 4(1), 143-150.

DOI : https:// doi.org/10.15294/lesrev.v4i1.38635

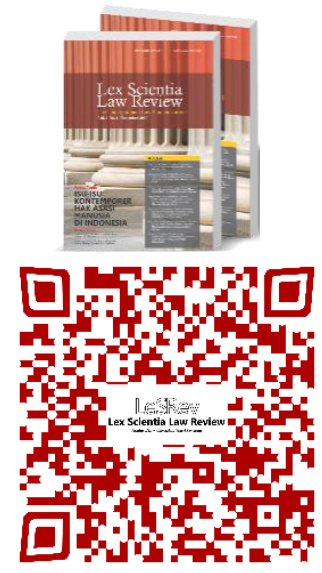

Vol. 4, No. 1

Month May Year 2020

@2020 by Authors 


\section{Introduction}

In 2019, Indonesian National Police succeeded in uncovering the case of trafficking of around 1,200 people who will be sent to countries in the Middle East. In an article published by BBC.com with the title "The biggest human trafficking revealed: 'I was sold to Iraq, raped, imprisoned" the resource person told me about his bad experience as a migrant worker. The name of the migrant worker, Jingga, is a pseudonym of 20 years old. Previously, Jingga was a factory worker from Tangerang, Banten. Jingga was enticed by her neighbors to work in Saudi Arabia with a salary of Rp. 5 million per month with a bonus of Rp. 5 million if he is declared healthy to work abroad. At that time, Jingga claimed that his monthly income was only Rp. 300,000 and the money cannot cover the cost of his life and his family. Because of the economic situation finally Jingga was determined to leave. When all the documents were ready, she was even asked by his agent to work for 2 weeks in Surabaya. After that in early 2018, she was sent to Malaysia, Dubai, Turkey, Sudan, Syria, to Iraq. Jingga claimed that she never received any salary. She even told me that during his three months in Syria she was often tortured by her employer. Together with his friend who came from Lombok he ventured to escape to the Indonesian Embassy (Embassy of the Republic of Indonesia) in Syria. But she was instead returned to her agent. While she was at the place of his agent who was in Damascus for one month she claimed to be tortured even though the agent's office was managed by Indonesian citizens. Jingga admitted that she had been beaten, her hair was cut and even her body was used as an exhibition to the office people. Jingga said that her suffering continued as long as she worked there. She was even made into the sexual gratification of his employer's children. When she complained to her employer she was accused of defaming a good name which made Jingga imprisoned in a state of 3 months pregnant. She was later released after being guaranteed by a lawyer for a humanitarian organization in Iraq, the Seed Foundation, and the International Organization for Migration (IOM).

Advances in information, communication and transportation technologies that accelerate the occurrence of globalization are used by criminals to cover slavery and servitude in new forms known as trafficking in persons. ${ }^{1}$ Human trafficking is a classic problem that has happened since ancient times. The crime of human trafficking is a form of transnational crime because this crime crosses one country to another. Today's human trafficking can be said to be modern slavery. This activity has become one of the threats of world crime because of its effects not only on economic aspects but also political, cultural and humanitarian aspects. Most of the objects of human trafficking are women and children because they are a vulnerable group. The case experienced by Jingga is one of the many cases of trafficking in persons. Director of Child Rehabilitation of the Ministry of Social Affairs Cupsanto said data from 2016 to mid2019, the number of victims of trafficking reached 4,906 people. ${ }^{2}$ The perpetrators of these crimes generally promise victims with the opportunity to get good jobs with high salaries and also opportunities to study abroad. But in reality they are instead used as

\footnotetext{
1 Sulaksono, E. (2016). Disharmoni Hak Migran di Wilayah Perbatasan Berimplikasi Kejahatan Perdagangan Manusia di Luar Negeri. Jurnal Keamanan Nasional, 2(1), 111-140.

${ }^{2}$ Maidian Reviani, (2019). Sampai Pertengahan Tahun Ini, 4.906 Orang Indonesia Jadi Korban Mafia Perdagangan Manusia. Retrieved from https://akurat.co/fokus/id-704217-read-sampai-pertengahan-tahunini-4906-orang-indonesia-jadi-korban-mafia-perdagangan-manusia, Accessed on May 52020.
} 
sexual or prostitution purposes, for domestic helpers without salary, for female workers, drug dealers, plantations, buskers and so on.

The main factors causing the rise of human trafficking are poverty, overcrowding, and patriarchal culture. However, poverty is the most dominant factor in human trafficking. People who have low levels of life are usually easier to target in human trafficking. The mode of perpetrators of these crimes is by way of providing jobs for a better quality of life. This situation is further strengthened by the large number of residents but few jobs. This makes them easily affected will get a good job. This is also reinforced by the patriarchal culture where most women are pressured by their surroundings. These factors make them an easy target to sell.

\section{Legal Issues}

Seeing how cruel and many cases of human trafficking are, therefore I take this case to analyze the law arising from the crime of human trafficking. Based on the background stated above, the following research problems can be formulated: first, what are the rules regarding trafficking in persons? Second, what are the rights violated by human trafficking perpetrators? Third, how are legal protection efforts for victims of human trafficking?

\section{Regulations regarding human trafficking}

Actually, the regulation of human trafficking has been set a long time ago. Human trafficking is classified as a transnational crime that has been a problem for countries in the world from the beginning until now. The international world, of course, highlighted this problem which eventually gave birth to several international conventions that have governed this, including:

1. International Convention for the Suppression of White Slave Traffic (International Convention to Erase the White Slave Trade) of 1921.

2. International Convention for the Suppression of Traffic in Women and Children (International Convention to Eradicate Trafficking of Women and Children) 1921.

3. International Convention for the Suppression of Traffic in Women of Full Age (International Convention to Eradicate Trafficking of Adult Women) 1933.

4. Convention on the Elimination of All Forms of Discrimination Againts Women, CEDAW (Convention on the Elimination of All Forms of Discrimination Against Women) in 1979.

With this international convention it is hoped that member countries will play an active role in preventing, protecting and enforcing law against human trafficking activities in their respective countries. In the case of human trafficking, women and children are the most vulnerable. So that Indonesia ratified the Convention on the Elimination of All Forms of Discrimination Againts Women, CEDAW (Convention on the Elimination of All Forms of Discrimination Against Women) in 1979 with The Act Number 7 of 1984 with Republic of Indonesia State Gazette of 1984 number 29. In 2000 the United Nations issued The Palermo Protocol or Palermo Convention 2000. In the palermo protocol reads: 
"Protocol to prevent, Suppress, and punish Trafficking in Persons, Especially Women and Children, Supplementing the United Nations Convention Against National Organized Crime"

The 2000 Palermo Protocol on Preventing, Eradicating and Punishing Trafficking in Persons, especially those who are victims of human trafficking are women and children. Legislation relating to trafficking in persons such as The Act Number 23 of 2002 concerning Child Protection and The Act Number 7 of 2002 concerning the ratification of CEDAW have not provided a comprehensive legal basis for this human trafficking. ${ }^{3}$ In providing protection to its citizens and to prevent trafficking in persons and to provide fair and just enforcement of these perpetrators, the Indonesian government established legislation is The Act Number 21 of 2007 concerning Eradication of the Criminal Act of Trafficking in Persons. In the law has layered criminal penalties. It not only provides imprisonment for traffickers but also imposes fines. Regarding victims in the case of trafficking in persons, the Indonesian government has also regulated in The Act number 13 of 2006 concerning Protection of Witnesses and Victims which is useful for protecting victims in the event of threats regarding providing witnesses.

\section{Rights violated by traffickers in human trafficking}

The discussion on human trafficking is related to human rights. These human rights do not exist because they have been given from the community or the state, but they have become the nature that already exists and has been brought by humans since birth given directly by God Almighty. At this time human rights have become the world's discussion in addition to environmental issues or democracy. Human rights have now become a demand for a country to be able to protect, defend and guarantee the continuation of the rights of every human being without discrimination. The Act Number 39 of 1999 states that human rights are a set of rights inherent in the nature and existence of humans as God's creatures and are His gifts that must be respected, upheld and protected by the state, law, government and every people for the honor and protection of human dignity.

Human trafficking receives attention from the perspective of Human Rights in Article 20 paragraphs 1 and 2 of The Act Number 39 of 1999 concerning Human Rights which states that slavery and servitude, slave trade, trafficking in women and all acts of any kind are for the purpose Similar is prohibited. Transnational crime perpetrators of human trafficking cases have violated human rights. The perpetrators of these crimes have violated human values. Based on The Act Number 21 of 2007 concerning Eradication of the Criminal Act of Trafficking in Persons considering the letter $b$, that trafficking in persons, especially women and children, is an act that is contrary to human dignity and violates human rights, so it must be eradicated. Furthermore, in letter $\mathrm{c}$ states that trafficking in persons has expanded in the form of organized and unorganized crime networks, both interstate and domestic, so that it becomes a threat to society, nation and state, and to the norms of life which are based on respect for the human rights.

In Indonesia, human trafficking is often carried out under the guise of offering victims to become an Indonesian migrant worker abroad. But what happened was the

\footnotetext{
${ }^{3}$ Novianti. (2014). Tinjauan Yuridis Kejahatan Perdagangan Manusia (Human Traffikking) Sebagai Kejahatan Lintas Batas Negara, Jurnal Imu Hukum, P. 57
} 
perpetrators committed the crime of human trafficking. In article 1 of The Act Number 21 of 2007 the perpetrators have fulfilled the elements, that are:

a. there are acts of recruitment, transportation, storage, delivery, transfer, or

b. acceptance of someone with the threat of violence, use of force, kidnapping, confinement,

c. forgery, fraud, abuse of power or vulnerable position, entrapment of debt or pay or benefit, thereby obtaining approval from the person in charge of that person,

d. carried out within the state, for the purpose of exploitation or to cause people to be exploited.

Perpetrators of human trafficking crimes have deprived human rights because they have exploited them to become domestic slaves without salary, sex slaves or prostitution, employing children, and marriage marriages that would normally be made slaves by her husband and husband's family. Article 33 paragraph 1 of The Act Number 39 of 1999 concerning Human Rights has affirmed that everyone must be free from torture, punishment or cruel, inhumane treatment, degrading the degree and dignity of their humanity. In 2015, the majority of victims of human trafficking syndicates were dominated by the Indonesian Migrant Workers (BMI) group known as the Indonesian Workers. ${ }^{4}$ It is indeed the irony of their lives, which aims and has good intentions to find work for a decent life instead, they are sold as slaves full of torture and used as material for sexual violence to fulfill the lust of employers. Jingga is the example of the case above that one of the many heartbreaking victims. Jingga was forced to work without a salary with pressure and pressure from the employer and even raped by the employer's child. This is what makes this crime must be completely eradicated because it has eliminated human freedom, which in fact they have human rights.

Regarding the punishment received by traffickers in accordance with Article 2 paragraph 1 of The Act Number 21 of 2007 concerning Eradication of the Criminal Act of Trafficking in Persons which states that any person who recruits, transports, holds, transfers, transfers, or receives a person with the threat of violence, the use of violence, kidnapping, confinement, counterfeiting, fraud, abuse of power or vulnerable position, debt bondage or payment or benefits despite obtaining approval from the person in control of another person, for the purpose of exploiting the person in the territory of the Republic of Indonesia, convicted with a criminal imprisonment for a minimum of 3 (three) years and a maximum of 15 (fifteen) years and a minimum fine of Rp. $120,000,000.00$ (one hundred and twenty million rupiah) and a maximum of Rp. $600,000,000.00$ (six hundred million rupiah). In Article 2 paragraph 2 it is explained that the perpetrators are punished if they cause someone to be exploited.

\section{Legal protection for victims of human trafficking.}

The existence of several conventions that discuss the irony of human trafficking held in the International sphere is proof that many countries are concerned about this problem. With conventions such as the 1979 CEDAW Conference that discussed the rights of women, it is hoped that from this society can eradicate acts of discrimination

\footnotetext{
${ }^{4}$ Everd Scor Rider Danield, et.al. (2015). Human Trafficking di Nusa Tenggara Timur. Social Work Jurnal Number 1. Volume 7.
} 
against women. Countries can ratify the results of the conference to respect women's rights.

Besides the existence of the Palermo Protocol, the Protocol on Preventing, Acting and Punishing (Actors) in Trafficking in Persons, Especially Women and Children, complements the existence of the 2000 United Nations Convention Transnational Organization Crime clearly regulates the protection of victims of human trafficking. This protocol also regulates the protection of victims both while in the recipient country and the repatriation of victims.

Cooperation between countries in tackling human trafficking is very good. The nations of the world care about the importance of human rights. They agreed to eradicate human trafficking and respond to it even giving aid to victims. The countries help victims by accommodating and even returning to their home countries at the expense of the recipient country. Particularly for victims who have legal problems in their traded countries, the country provides an opportunity for the country of origin to help its citizens for justice.

Regarding legal protection for victims in Indonesia, it has been regulated in Chapter V regarding the protection of witnesses and victims in The Act Number 21 of 2007 concerning Eradication of Criminal Acts of Trafficking in Persons. Article 43 states that the Provisions on the Protection of Witnesses and Victims in Criminal Acts of Trafficking in Persons shall be implemented according to The Act Number 13 of 2006 concerning Protection of Witnesses and Victims, unless otherwise stipulated in this Law. If there is a violation of the law committed by the victim abroad in article 53 of The Act Number 21 of 2007 states that the state is obliged to protect and benefit the victim and try to be repatriated.

If seen from the laws and regulations, The Act Number 21 of 2007 is better considering the concept of victim protection is not only oriented towards potential victims but also to the actual victims. ${ }^{5}$ Protection efforts undertaken by countries in the world have been very good. Evidenced by their serious efforts in protecting victims and preventing human trafficking by ratifying some of the results of international conferences, protocols, and some international agreements.

\section{Conclusion}

The case experienced by Jingga is a form of human trafficking. Jingga was offered overseas work by his neighbors, but in reality was exploited. Jingga claimed to have been mistreated by her employer and even raped. Human trafficking is a form of transnational crime because this crime crosses countries. Human trafficking today is the same as modern slavery. This crime is mostly experienced by vulnerable groups, are children and women. The perpetrators mostly offered victims a decent job overseas and would get an education. The main factors causing the rise of human trafficking are poverty, overcrowding, and patriarchal culture. Because of these factors, it makes it easy for brands to become victims of human trafficking.

Regulations regarding human trafficking have been regulated a long time ago by the international community through several conventions including the International Convention for the Suppression of White Slave

\footnotetext{
${ }^{5}$ Novianti, Op cit, P. 63
}

https://journal.unnes.ac.id/sju/index.php/lsIr/ 
Traffic (1921 International Convention for the Elimination of White Slave Trade), International Convention for the Suppression of Traffic in Women and Children (International Convention to Eliminate Trafficking of Women and Children) 1921, International Convention for the Suppression of Traffic in Women of Full Age (International Convention to Eliminate Trafficking of Adult Women) 1933, Convention on the Elimination of All Forms of Discrimination Againts Women, CEDAW (Convention on the Elimination of All Forms of Discrimination Against Women) in 1979. With these conventions member states are expected to be able to apply or ratify them into law. Indonesia ratified the Convention on the Elimination of All Forms of Discrimination Againts Women, CEDAW (Convention on the Elimination of All Forms of Discrimination Against Women) in 1979 with The Act Number 7 of 1984 with Republic of Indonesia State Gazette of 1984 number 29. In 2000 the United Nations issued a Protocol Palermo. The 2000 Palermo Protocol on Preventing, Eradicating and Punishing Trafficking in Persons, especially those who are victims of trafficking in women and children. With the existence of several conventions and the existence of this palermo protocol which eventually gave birth to the Act Number 21 of 2007 concerning Eradication of the Criminal Act of Trafficking in Persons.

Traffickers have violated human rights because they exploit someone as if the person has no value. Human trafficking receives attention from the perspective of Human Rights in Article 20 paragraphs 1 and 2 of The Act Number 39 of 1999 concerning Human Rights which states that slavery and servitude, slave trade, trafficking in women and all acts of any kind are for the purpose Similar is prohibited.

Legal protection efforts for victims are good. It was proven by the concern of the international community towards victims. Conducting conventions and issuing protocols is a serious step in handling human trafficking. Regarding legal protection for victims in Indonesia, it has been regulated in Chapter $\mathrm{V}$ regarding the protection of witnesses and victims in the The Act Number 21 of 2007 concerning Eradication of Criminal Acts of Trafficking in Persons. Article 43 states that the Provisions on the Protection of Witnesses and Victims in criminal Acts of Trafficking in Persons shall be implemented according to The Act Number 13 of 2006 concerning Protection of Witnesses and Victims, unless otherwise stipulated in this Law. 


\section{References}

\section{Journal}

Damanik, J. (2013). Penerapan Sanksi Hukum Terhadap Pelaku Kejahatan Trafficking (Studi Putusan di Pengadilan Negeri Binjai) (Doctoral dissertation, Universitas Medan Area).

Daniel, Everd S. R, et.al. 2015. Human Trafficking di Nusa Tenggara Timur. Social Work Jurnal Number 1 Volume 7.

Hakim, L. (2020). Analisis Ketidak Efektifan Prosedur Penyelesaian Hak Restitusi Bagi Korban Tindak Pidana Perdagangan Manusia (Trafficking). Jurnal Kajian Ilmiah. 20(1), 43-58.

Jamilah, A., \& Jaya, N. S. P. (2020). Penanggulangan Kejahatan Perdagangan Orang Dari Perspektif Politik Kriminal di Indonesia. JUSTITIA JURNAL HUKUM, 4(1).

Novianti. (2014). TINJAUAN YURIDIS KEJAHATAN PERDAGANGAN MANUSIA (HUMAN TRAFFIKKING) SEBAGAI KEJAHATAN LINTAS BATAS NEGARA. Jurnal Ilmu Hukum.

Sitania, L. V., \& Suponyono, E. (2020). AKOMODASI PEMBERANTASAN TINDAK PIDANA PERDAGANGAN ORANG DALAM ASPEK HUKUM INTERNASIONAL DAN NASIONAL. Jurnal Pembangunan Hukum Indonesia, 2(1), 38-54.

Sulaksono, E. (2016). Disharmoni Hak Migran di Wilayah Perbatasan Berimplikasi Kejahatan Perdagangan Manusia di Luar Negeri. Jurnal Keamanan Nasional, 2(1), 111-140.

Sulaksono, E. (2016). Disharmoni Hak Migran di Wilayah Perbatasan Berimplikasi Kejahatan Perdagangan Manusia di Luar Negeri. Jurnal Keamanan Nasional, 2(1), 111-140.

Takariawan, A., \& Putri, S. A. (2018). Perlindungan Hukum terhadap Korban Human Trafficking dalam Perspektif Hak Asasi Manusia. Jurnal Hukum IUS QUIA IUSTUM, 25(2), 237-255.

Yusitarani, S. (2020). ANALISIS YURIDIS PERLINDUNGAN HUKUM TENAGA MIGRAN KORBAN PERDAGANGAN MANUSIA OLEH PEMERINTAH INDONESIA. Jurnal Pembangunan Hukum Indonesia, 2(1), 24-37.

\section{Online}

Maidian, Reviani. (2019). Sampai Pertengahan Tahun Ini, 4.906 Orang Indonesia Jadi Korban Mafia Perdagangan Manusia, Retrieved from https://akurat.co/fokus/id704217-read-sampai-pertengahan-tahun-ini-4906-orang-indonesia-jadi-korbanmafia-perdagangan-manusia , Accessed on May 12020.

Wijaya, Callistasia.(2019). Perdagangan manusia terbesar terunkap : " Saya dijual ke Irak, diperkosa, dipenjara. Retrieved from : https://www.bbc.com/indonesia/indonesia-47877938, Accessed on May 12020. 
E-ISSN: 2598-9685，P-ISSN: 2598-9677

https://journal.unnes.ac.id/sju/index.php/lsIr/ Copyright (c) 2020 By Authors 